\title{
児童期の知能・学力に関する研究 $(3)$
}

\author{
一学力とコンピテンスの関係一 \\ ○宮本友弘・都築忠義・相良順子・家近早苗（非会員） \\ (聖徳大学児童学部) \\ キーワード : 児童期, 学力, コンピテンス
}

\begin{abstract}
Research on intelligence and academic performance in childhood III: Relation between academic performance and competence
\end{abstract}
Tomohiro MIYAMOTO, Tadayoshi TSUZUKI, Junko SAGARA and Sanae IECHIKA ${ }^{\#}$

(Faculty of Child Studies, Seitoku University)

Key Words: childhood, academic performance, competence

\section{目 的}

本研究では児童期の学力と学習コンピテンスの関係につい て検討する。桜井 (1983) は小学 3 年生〜中学 3 年生にかけて 学習コンピテンスが低下傾向にあることを示したが、小学 5 年生と小学 6 年生を比較した別の研究(桜井, 1992)では差が みられなかった。このように学年変化の様相は一貫しておら ず、また、学力との直接的な関連性については十分に検討さ れてはいない。そこで、あらためて小学 4〜6 年生のコンピテ ンスの様相を探るとともに、学力との関連性を検討する。

\section{方 法}

調査対象者 私立大学附属小学校 4 年生 83 名 (男子 34 名、 女子 49 名）、 5 年生 87 名（男子 40 名、女子 47 名）、6 年生 80 名（男子 31 名、女子 49 名）。

質問紙 (1)興味や関心をもっていること：16 項目（読書・ 音楽・ままごと等）に対して 3 件法で回答を求めた。(2)児童 用コンピテンス尺度 (桜井, 1992) : 児童の回答負担を考慮し、 4 つの下位尺度のうち、学習コンピテンス (以下、学習)、社 会コンピテンス（以下、社会）、自己価值の 3 つを使用した。 各 10 項目、4 件法による回答。

学力の指標 協力校が毎年 2 月に実施してきた教研式標準 学力検査 NRT の結果（全国基準による偏差值）を使用した。 入学後、2 年生までは国語、算数の 2 教科、3 年生以降は社会、 理科を加えて 4 教科が実施された。

手続き 質問紙調査は 2012 年 3 月に実施された。クラスご とに担任が配布、回収した。本研究では児童用コンピテンス について分析した。また、学力の指標については教科間相互 に強い相関が認められたので、全学年を通して実施されてい る国語と算数の合計值を用いた。

\section{結 果}

コンピテンスの学年変化 図 1 に各学年の下位尺度得点の 平均值を示した。3 (学年) $\times 2$ (性)の分散分析を行った。学習 では学年の主効果が有意であったが $(\mathrm{F}(2,229)=3.11, \mathrm{p}<.05) 、$ 多重比較の結果では 5\%水準の有意差はみられなかった。性 の主効果も有意で女子<男子であった $(\mathrm{F}(1,229)=18.65$, $\mathrm{p}<.01)$ 。社会では学年の主効果のみが有意で $(\mathrm{F}(2,227)=4.28$, $\mathrm{p}<.05) 、 6$ 年 $<4$ 年であった。自己価值では学年の主効果が有 意で $(\mathrm{F}(2,225)=9.50, \mathrm{p}<.01) 、 5$ 年、6 年 $<4$ 年であった。 性の主効果も有意で女子＜男子であった（F（1，225）=6.54, $\mathrm{p}<.01)$ 。

コンピテンス相互の関連 自己価值を従属変数、学習、社 会を独立変数にして重回帰分析を行った。その結果、4 年生 で $R^{2}=.61$ 、学習 $\beta=.46$ 、社会 $\beta=.43 、 5$ 年生で $R^{2}=.61$ 、学習 $\beta=.41$ 、社会 $\beta=.51 、 6$ 年生で $R^{2}=.58$ 、学習 $\beta=.36$ 、社会 $\beta$ $=.55$ であった（ $\beta$ はすべて $\mathrm{p}<.01 ） 。$

学カと学習コンピテンスの関連 現学年の成績と学習コン ピテンスの相関を求めた結果（表 1 ）、有意な正の相関が認め られた。また、単回帰分析によって過去の各学年時の成績か ら予測される現学年の成績と実際の成績の差 (残差) を求め、
学習コンピテンスとの相関を求めた。表 1 の通り、いずれの 学年においても、予測時の学年がより低いほじ、学習コンピ テンスとの相関は強かった。

\section{考 察}

いずれのコンピテンスも 4 年から 5 年にかけて低下し、5 年と 6 年生はほぼ同水準であった。先行研究と異なる傾向で あり、今後さらなる検討が必要である。男女差については先 行研究と同様であった。また、全学年ともに自己価值は学習 と社会の両コンピテンスから同等の影響を受けており、学習 面の有能感だけで自己価值が決定づけられるわけではなかっ た。さらに、学習コンピテンスは、現在の学力が、低学年時 の学力から予測される学力よりもプラスに変化しているほじ、 高かった。現在の成績だけでなく低学年からの成績の向上も 中高学年の学習コンピテンスに影響する可能性が示唆された。

\section{引用文献}

桜井茂男 (1983)。認知されたコンピテンス測定尺度 (日本語 版)の作成 教育心理学研究，31，245-249.

桜井茂男 (1992). 小学校高学年生における自己意識の検討 実験社会心理学研究, 32, 85-94.

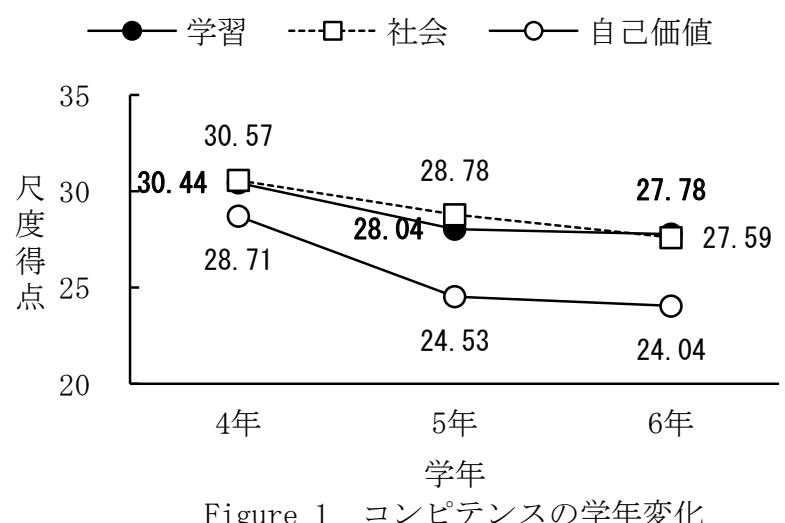

Table 1 現学年の成績、及び、各学年時成績から予測さ れる成績との残差、と学習コンピテンスの相関

\begin{tabular}{lccc}
\hline & 4 年 & 5 年 & 6 年 \\
\hline 現学年の成績 & $.712^{* *}$ & $.590^{* *}$ & $.681^{* *}$ \\
5 年時予測成績との残差 & - & - & -.028 \\
4 年時予測成績との残差 & - & $.242^{*}$ & .063 \\
3 年時予測成績との残差 & $.321^{* *}$ & $.287^{*}$ & .188 \\
2 年時予測成績との残差 & $.425^{* *}$ & $.287^{*}$ & $.278^{*}$ \\
1 年時予測成績との残差 & $.535^{* *}$ & $.434^{* *}$ & $.415^{* *}$ \\
\hline${ }^{* *} p<.01{ }^{*} p \nmid .05$ & \multicolumn{3}{|}{} \\
本研究は科研費 ${ }^{*}(23653209)$ & の助成を受けた。
\end{tabular}

